\title{
Equal Opportunities and Dignity as Values in the Perspective of I. Kant's Deontological Ethics: The Case of Inclusive Education
}

\author{
VILIJA GRINCEVIČIENÉ , JOVILE் BAREVIČIŪTÉ², \\ VAIDA ASAKAVIČIŪTÉ2 ${ }^{2}$ VILIJA TARGAMADZE் \\ 'Department of Philosophy and Cultural Studies, Faculty of Creative Industries, Vilnius Gediminas Technical University, Trakų St. 1, \\ 01132 Vilnius, Lithuania \\ ${ }^{2}$ Department of Entertainment Industries, Faculty of Creative Industries, Vilnius Gediminas Technical University, Trakų St. 1, 01132 \\ Vilnius, Lithuania \\ ${ }^{3}$ Faculty of Philosophy, Vilnius University, University St. 9/1,01513 Vilnius, Lithuania \\ Email: vilija.grinceviciene@vgtu.lt; jovile.bareviciute@vgtu.lt; vaida.asakaviciute@vgtu.It; vilija.targamadze@fst.vu.It
}

\begin{abstract}
The article attempts to reveal the correlation of values, attitudes and their place in the system of individual ant societal value development with maturity, culture, ideology and social domain (especially education) change areas and tendencies of the society which the person belongs to. The main thesis of the article - changing of values and their place in the conglomeration of societal values - presupposed the changing of educational domain and its tendencies, one of which is inclusive education. The minor thesis follows from the major one - persons, affected by disability (children, teenagers and youth), and their relatives still face difficulties in pursuing education: equal opportunities and dignity as values in individual cases are still to be achieved. After analysing the aspects of changes in special education, it becomes clear that the legal basis for regulation, established in the country, only in theory warrants equal opportunities for everyone pursuing education. Data from long-term studies show that disabled people often encounter difficulties in educational reality. Values, interpreted from the perspective of Kant's deontological ethics and categorical imperative and declared in normative documents regulating the educational system, in reality have not reach the rank of basic values: in the process of education disabled people are nevertheless occasionally ignored and discriminated.
\end{abstract}

Keywords: values, attitudes, inclusive education, disability, Kant, deontological ethics, obligation, categorical imperative, the Other, otherness

\section{INTRODUCTION}

In modern scientific domain the term value is explained rather differently, which is an obvious example of pluralism. Problems of the existential and gnoseological state of values are somewhat differently analysed and interpreted by philosophical trends (realism, idealism, 
humanism, scepticism, subjectivism, objectivism, etc.) ${ }^{1}$, different accents in the aforementioned problematics are stressed by culture, religion, the country's political, economic and, especially, its system of education. In recent ongoing discussions about what should be regarded as values in the conditions of a globalized information society, the analysis of value types and ways of their visual expression is done mainly by the representatives of the humanities and social sciences. Since ancient times, since the pre-Socratics, to be precise, values as one of the most important aspects of social and cultural life got into the perspective of philosophical thinking. The pre-Socratic philosophers, who belonged to different philosophical trends, set themselves a goal to strive for good and identified it with different values. One of the main positions in this context was stoicism which propagated justice, encouraged one to follow wisdom, to be brave, extolled temperance, modesty and moderation as fundamental values of life which pave the way for the successful and happy existence of society as well as for the life of all its members (Seneca 2016, 2009; Epictetus 2009; Marcus Aurelius 2018). Plato (2006) and Balčius (1996) also propagated good as the highest value whose image became the Sun and whose care embraces all who live in this world - under the Sun - both the abled and the disabled. The value of moderation as the golden mean was also preached by Aristotle (2011). In the context of this article, moderation means patience, forbearance, tolerance, decency and assurance of equal opportunities to all. A representative of Christian ethics Aurelius Augustinus formulates the concept of freedom as a task: freedom is the goal of aspiration $(1993,2008$; Brown 1997; Marion 2012), therefore, freedom to pursue one's goals, including education, has to be assured to all. This is the only way to assure the strife for the fullness of existence, considered by Thomas Aquinas, to all members of society without exception, overcoming the phenomenon of an 'erroneous consciousness' (1998) perceived by him. These and many other interpretations of values since the 19-20th centuries have also extended to problems analysed in the sphere of social values. Thus it is obviously interdisciplinary and multidimensional problematics. Moreover, when we speak about any moral virtue, we are concerned not with practical actions which we see, but with their innate principles which are invisible. This Immanuel Kant's thought (1724-1804) (2013) can be regarded as a platform which presupposes a discourse on the thematics of value typology and their expression in the modern socium. In scientific discussions on the typological aspects of values, the general consensus is on the transcendental (the highest, eternal, spiritual) realm of values. These are cardinal, eternal values, the main parts of the plan of human life and existence which resist time and are handed on from one generation to another and are engrained in human consciousness as the chief goals and aims of life. The values of this type function on cognitive, emotional and behavioural planes. Treat others as you would want them to treat you - this categorical imperative of deontological ethics promoted by the forefather of German classical philosophy can be viewed as a testament (ideal) and our goal. However, goals without acquiring/developing and internalizing certain value orientations tend to remain only goals... According to L. Jovaiša, a value orientation is the acquired faculty of consciousness to regulate one's activity and behaviour according to one's convictions, moral standards and life prospects, to perceive what is worthless and hostile in the person's and society's life (Jovaiša 2007: 326). According to V. Pruskus, in choosing values, people reveal indirectly their goals and ideals which are close and important for them (2016: 199-205). These ideals have a universal character. And the universality of the ideal (aim) stimulates one to create and maintain standards

\footnotetext{
1 For the creative and innovative approach to traditional moral values see Kanišauskas 2018, Kačerauskas 2019.
} 
as a precondition for the existence of these ideals, differentiate one from another. And above all, they help the individual more purposefully realize his goals (e.g. security and co-operation) which cannot be attained if their standards are not clearly named.

The fundamental values coexist with values of other types. They are important to individual social layers at different stages of the development of socium. These are temporary (partial, artificial) values fostered by separate social or professional groups (Pruskus 2005: 29). Values of this type are not resistant to time, and their meaning, importance and weight among the value orientations of society have a tendency to change. Being supported by society, partial (artificial, temporary) values can become fundamental in due course of time. Taking into consideration the society's recent concern for equal opportunities and dignity, for their expression in the conglomeration of value orientations, it can be inferred that these values in the modern socium are accepted as exceptional. Thus one can assume that equal opportunities and dignity in the conditions of a globalized information society will become the fundamental values as goals and an extension of Kant's categorical imperative, which will deny the narrow utilitarianism that reduces people to individuals who only bring or earn profit (Salzmann 1995: 76) and who refute the meaning and significance of duty extolled by Kant, especially to the disabled, their relatives and all the participants in education. This is testified by the essential changes in the socium: the legal system that has been formed in the country, the appropriate models of social policy, health care and education as well as the rapidly growing processes of humanization of the environment (personal and public). Thus it is obvious that many expectations held by disabled people, their relatives, the participants in education as well as each of us have come true. It is a result of hard, intensive, consistent and purposeful work which has been forming the attitude of every member of the society to the disabled and makes one reappraise their attitudes and internalize the relevant values. Taking into account tendencies of a changing attitude to the disabled, the two turning points become obvious: negativism - positivism. It should be stressed that the problematics of values were examined already by the aforementioned ancient thinkers Socrates, Plato, Aristotle, and others. According to V. Gudonis, the attitude to the disabled in ancient times also depended on the system of values in separate poles (2000: 40).

From the philosophical perspective, values are the objective rules necessary for an individual mode of life and social co-operation, orientation models and norms of behaviour which people have to conform to in their subjective evaluation of the relevant phenomena, in thinking and in controlling their actions (Halder 2002: 229). It is worth considering the aforementioned values of man's rights and dignity, which are relevant nowadays, and which in the philosophical perspective have become one of the cornerstones of Kant's ethics. On the basis of Kant's deontological principles, humankind and individual societies as well as separate individuals have to be treated as an ultimate purpose. The latter is inextricable from good will which is also an ultimate end. Such Kantian position is a firm theoretical basis for solutions to moral questions of human rights and dignity ${ }^{2}$ which arise in the contemporary society. Thus the individual, society and humankind are the three main footholds which allow the formation of the so-called 'respect for autonomy' and reinforce it as the essential idea of Kant's ethics (Dean 2006).

The main thesis of the article - changing of values and their place in the conglomeration of societal values - presupposed the changing of special educational domain and its tendencies, one of which is inclusive education (see more Beacham, Rouse 2012). The minor thesis is

\footnotetext{
2 For detailed discussion on moral decision making in relationship with moral assessment, see Nadurak 2018.
} 
developed from the major one - persons affected by disability (children, teenagers and youth) and their relatives still face difficulties in pursuing education: equal opportunities and dignity as values in individual cases are still to be achieved. The elaboration of the minor thesis is determined by the major one. The beginning of the article concisely discusses the factors which have most likely contributed to the process of changing of values in our society and presupposed the development of special educational domain (tendency of inclusive education). Further on, an attempt is made to answer the question whether disabled people in today's socium do not feel discriminated against and whether equal opportunities in education are warranted. Thus, can one claim that equal opportunities and dignity as values in our society are regarded as exceptional and have reached the range of fundamental values? The research draws on Kant's deontological ethics, ideas of the paradigm of free education and philosophy of education which is based on the attitudes of humanism and progressivism: high-quality education is the one which corresponds to the person's nature and needs, stimulates one to improve himself; the learner is a free, independent and unique personality; the process of education takes place in an emotionally positive environment in which the participants positively communicate and co-operate. It also draws on Kant's thoughts and ideas with regard to values, dignity, freedom and responsibility as well as the categorical imperative to treat others as you would want them to treat you, which reveals the attitudes of Christian ethics.

\section{NORMATIVE AND VALUE-BASED ASPECTS OF CHANGES IN SPECIAL EDUCATION}

The key internationally and nationally adopted documents that regulate the national social policy and educational system - UN Convention on the Rights of the Child (1989), Salamanca Statement (1996), Law on Education of the Republic of Lithuania (1991 and its later versions), Law on Higher Education and Research of the Republic of Lithuania (2009), Curricular of General Education in Lithuania (1997), State Education Strategy for 2013-2022, National Progress Strategy 'Lithuania 2030' and research studies of scholars (Anilionyte 1990; Gudonis 2000; Kuzmickas 2013; Pruskus 2005, 2015, 2016, and others) - provide for a targeted and consistent formation of a positive attitude towards inclusive education laying emphasis on assurance of education availability and equal opportunities at all levels of education. The above-mentioned documents underline the necessity for providing timely pedagogical and psychological support to school learners, who face learning difficulties. Moreover, educational policy makers, strategists, participants in education and all the members of society are as if faced with the necessity to act in a targeted and consistent way to presuppose the transition of such values as dignity and equal opportunities into the range of fundamental ones. Thus, evaluating the situation from the theoretical approaches, the result is obvious: our society members acknowledge that the disabled individuals have the right to equal opportunities and to act with dignity pursuing self-development and education.

The transformations introduced into the system of education have led to targeted changes in the model of education for disabled children and young people: the space for reforms in special education has directed educational institutions towards integrated education and training of disabled youth for career. Inclusive education is one of them. This approach orient families as well as schools to act jointly, in a sustainable and creative way, because our society has reached the stage in its development when accessibility of education for every individual has become a reality. The United Nations have been playing a significant role in this activity.

In this context of the perspective of Kant's ethics, there emerges a duty assigned to society to provide its every member with the best possible conditions for learning, studies 
and work, i.e. to ensure successful integration of every member into socium. Fulfilment of this duty is a fundamental moral action because according to the interpretation of the principles of Kant's ethics by J. Girnius, 'our activity has a moral meaning only as long as it is conducted for implementation of a relative law' (Girnius 1991: 67). In other words, observation of laws and supplementing directives is directly related to moral behaviour and moral norms. Therefore, violating any of the previously adopted provisions and laws, we tend to break the categorical imperative of Kant's ethics, which is grounded on treating another person as a goal rather than a means. It is important to emphasise that legally unregulated and critically unquestioned inclinations of an individual are not in line with the previously mentioned imperative suggested by Kant as they mainly contradict the duty. Only duties and understanding of moral law pave the path for conscious and human well-being of an individual and society that is based on morality. From the perspective of Kant's ethics, any laws in force in any state have to be approached as regulated expression of the universal law of morality. Therefore, comprehensively successful integration of disabled individuals into society is a duty assigned to us, non-disabled individuals without accepting any connotations of benefit or subjective inclinations. This thought is supplemented by Kant (2013), who states that pure duties without any empirical incentives and general understanding of the law of morality though reasoning act much stronger than all incentives generated by empirical domain. Therefore, this approach is what grounds the attitude towards non-disabled and disabled people refusing to follow subjective feelings, predispositions and inclinations, which, according to Kant, make the spirit of an individual shake (Kant 2013) and motivate him or her to act under influence of selfish motives. The latter factors impede integrated education, which is discussed further.

\section{EQUAL OPPORTUNITIES AND DIGNITY IN EDUCATION: ASPIRATION OR REALITY?}

The texts of I. Kant obviously show that defending human rights to freedom, a philosopher defends responsibility and dignity, rights and duties: treat others as you'd like to be treated... Thus, manifestations of the principle of equality (equal opportunities) and parity can be envisaged: the ability of every person to be dignified, moral and honest is actualised. And not only this: the main attention and key focuses are allocated to the attention directed towards another person, maximum respect to the one the way he or she is, approaching a person as a goal rather than a means (see more González 2017). Only in the perspective of treating the Other as alterity, the Other emerges as a mystery worth respect but not because of certain achievements but rather owning to their intrinsic (inborn human) essence. Such a glimpse to the Other as alterity is a necessary condition for establishing a dialogue with the Other, which leads to emergence of You as a subject but not to that of It as an object. This aspect fully approximates us to the value principles of M. Buber's ethics (2000). Such an approach to the Other as alterity from the perspective of Kant's ethics opens up as a formal requirement and as a necessity, which, in the case of this article, is assigned to the able ones: Kant seeks to consolidate the status of individual's intrinsic, autonomous value and his or her duty as an obligation (Budryte 2004: 27). Only under conditions when duties are perceived as an obligation and necessity, it is possible to speak of assurance of human rights and dignity in society. The reception of the above-mentioned ideas and thoughts of I. Kant is obvious in the texts of the above-mentioned normative legal acts, which provide for equal opportunities to all the members of society. So, are equal opportunities and dignity still an aspiration or reality already available in national education? 
The analysis of longitudinal research data (Grincevičienè 2010; 2015) revealed that positive attitudes of society (school learners' parents) towards the disabled frequently become negative when the latter interfere into their personal space. Therefore, seeking social solidarity and social integration in education, targeted, consistent and parallel actions, both at the theoretical and practical space of socium expression, have to be performed. It is particularly important to introduce relevant corrections into the curriculum of teacher education institutions: the study subject of special pedagogy has to become obligatory to prospective teachers, during their teaching practices they have to familiarise with adapted and modified educational programmes and to communicate with special need learners.

In the beginning of the research period (2002) half of the respondents (school learners' parents) expressed an opinion that disabled children could learn together with their peers in the same classes. This is a model of natural integration that naturally reflects the values of Kant's deontological ethics and individuals' parity based on those values, an obligation to establish a dialogue with the Other accepting his or her alterity or considering him or her not as an object that is worth pity, or even worse, contempt but rather as You, who is equal to me. Let us return to the previously mentioned research. The representative quantitative survey that was repeated ten years later disclosed an obvious change in the parents' attitudes: every second respondent (father, mother or caregiver of learner/s) pointed out that they agree with integration of disabled children to general education institutions only if they learn in separate classes. Thus, the research results show that the reforms of the system of national education have not led to establishment of a school, where all school learners could learn together on an equal basis. In the perspective of the philosophical-axiological approach, such a priori situation predetermines an insufficient respect for the Other as alterity, for acceptance of disability of the other, sympathy or contempt for him or her. In such a way the Kant's categorical imperative is roughly violated and the universality of the law of maximum respect and obligation to the Other, which was declared by Kant, is limited. Any isolation (exclusion) of the Other from the so-called able already predetermines the attitude of the latter towards the other as a weaker or disabled object, i.e. unequal to the able one, and the opportunity to establish an equal dialogue with the Other is lost: this Other is approached not as a respectable subject, not as You but rather as an object, as It to be manipulated. The question therefore arises if the disabled in our society are really under-appreciated, seen as outcasts or just pitied. Are rights and dignity of people with disabilities and, consequently, the categorical imperative grounded on Kant's parity principle really violated?

The current situation can be commented on from different perspectives: equal opportunities and dignity as values are obviously supported in our society but not all the members of society have been through deep internalisation of them (see more Belas, Belasova 2017). Controversially, diversity should be approached and appreciated as potential resources rather than problems: this would lead to the maximal implementation of Kant's categorical imperative. All what remains is hope and belief that our society will make more determined judgements regarding equal opportunities and dignity as exceptional values and will support them stronger in future. Do the above-mentioned values have any possibility of going up and reaching the range of fundamental values? It can be stated that ability of every member of society to retain own judgement acquires significance: a strong intrinsic motivation to internalise European values - respect for human rights, tolerance and equal opportunities - ensures that equal opportunities and dignity, as exceptional values in the today's socium, will naturally grow and reach the range of fundamental values. 


\section{CONCLUSIONS}

The role of values and value-based attitudes in the system of value development of an individual and society evidences the maturity, culture, ideology spaces and directions of changes in social sphere (education in particular) observed in the society an individual belongs to. By reviewing and analysing the aspects of changes in national special education, it seems that by acting consistently and purposefully (acknowledging European values) a stable basis of legal legislation has been created, which ensures legal opportunities for each individual at a theoretical level; theoretical approaches to changes in special education and a new direction represented by inclusive education offer a possibility for disabled members of society to choose the most appropriate path for them and to pursue education in a dignified way.

The data of the longitudinal quantitative research reveal that the values declared in the normative documents regulating the system of education have not reached the range of fundamental values in the reality so far: the disabled people are frequently ignored, discriminated against or face various obstacles in the process of education. Some children and young people learn in the environments that are isolated from their peers. In the light of Kant's deontological ethics, such a situation evidences violation of parity, autonomy and the instinct value of the Other as alterity, objectification of the subject of the Other and understatement of individual's value.

Received 18 September 2018 Accepted 5 February 2019

\section{References}

1. Anilionytè, L. 1990. „Vertybių problema I. Kanto etikoje“, Problemos 44: 48-54.

2. Aristotle. 2001. Nicomachean Ethics. Chicago: The University of Chicago Press.

3. Augustine. 1993. On Free Choice of the Will. Indianapolis/Cambridge: Hackett Publishing Company, Inc.

4. Balčius, J. 1996. Platono etika. Vilnius: Lietuvos filosofijos ir sociologijos institutas.

5. Beacham, N.; Rouse, M. 2012. "Student Teachers' Attitudes and Beliefs about Inclusion and Inclusive Practice", Journal of Research in Special Educational Needs 12(1): 3-11.

6. Belas, L.; Belasova, L. 2017. "Contemporary Society in the Context of Kant's Practical Philosophy", Filosofija. Sociologija 28(3): 204-211.

7. Brown, P. 1997. Augustinas iš Hipono. Vilnius: Taura.

8. Buber, M. 2000. I and Thou. New York, NY: Scribner Classics.

9. Budrytė, E. 2004. „Dvi pareigos sampratos: Nietzsche ir Kantas“, Žmogus ir žodis 4: 27-31.

10. Dean, R. 2006. The Value of Humanity in Kant's Moral Theory. Oxford: Oxford University Press.

11. Epictetus. 2009. Handbook of Epictetus. New York: Classic Books America.

12. Girnius, J. 1991. „Karl Jasperso egzistencinè metafizika“, iš Raštai, sud. G. Bautrènienè. T. 1. Vilnius: Mintis, 3-132.

13. González, A. M. 2017. “The Pending Revolution: Kant as a Moral Revolutionary”, Filosofija. Sociologija 28(3): 194-203.

14. Grincevičienè, V. 2010. Mokyklos kaitos erdvés ir linkmès. Vilnius: Vilniaus pedagoginis universitetas.

15. Grincevičienè, V.; Szerlag, A.; Dziubacka, K.; Targamadzė, V. 2015. „Itraukusis ugdymas: mokinių tèvų rūpesčiai ir lūkesčiai“, Santalka: filologija, edukologija 23(1): 73-80.

16. Gudonis, V. 2000. „Požiūris ị neịgalų žmogų antikos epochoje“, iš Neigalus ugdytinis švietimo sistemos kaitos kontekste, 33-41.

17. Halder, A. 2002. Filosofijos žodynas. Vilnius: Alma littera, 229.

18. Jovaiša, L. 2007. Enciklopedinis edukologijos žodynas. Vilnius: Gimtasis žodis, 326.

19. Kačerauskas, T. 2019. "Ethics in Business and Communication: Common Ground or Incommensurable?", E+M Ekonomie a Management 22(1): 72-81.

20. Kanišauskas, S. 2018. "Devaluation of Values or a Creative Need to Transcend into the Depth?", Creativity Studies 11(2): 273-283. 
21. Kant, I. 2013. The Metaphysics of Morals. Ed. M. Gregor. Series: Cambridge Texts in the History of Philosophy, eds. K. Ameriks and D. M. Clarke. Cambridge: Cambridge University Press.

22. Kuzmickas, B. 2013. Vertybès kultūrų kontekstuose. Vilnius: Mykolo Romerio universitetas.

23. LR Seimas. 2010. „Neiggaliụjų teisių konvencija ir jos Fakultatyvus protokolas“, Valstybès žinios, 713561.

24. LR Seimas. 2011. „Lietuvos Respublikos švietimo įstatymo pakeitimo įstatymas. Nr. XI-1281“, Valstybès žinios Nr. 38-1804.

25. LR Seimas. 2012. „Dèl Valstybinès pažangos strategijos,Lietuva 2030“patvirtinimo“. 2012 m. gegužès $15 \mathrm{~d}$. Nr. XI-2015. Prieiga per internetą: http://www.smm.lt

26. LR Seimas. 2013. „Dèl Valstybinès švietimo 2013-2022 metų strategijos nuostatų patvirtinimo. 2013 m. gruodžio 23 d. Nr. XII-745“, Valstybés žinios Nr. 140-7095.

27. LR Seimas. 1995. „Vaiko teisių konvencija“ (Priimta Generalinès Asamblejos 44/25 rezoliucija pagal Trečiojo komiteto pranešimą (A/44/736 ir Corr. 1), Valstybès žinios Nr. 60-1501.

28. LR Seimas. 2009. „Lietuvos Respublikos mokslo ir studiju įstatymas. 2009 m. balandžio $30 \mathrm{~d}$. Nr. XI-242“, Valstybès žinios Nr. 54-2140.

29. LR Švietimo ir mokslo ministerija. 1997. Lietuvos bendrojo lavinimo mokyklos bendrosios programos.

30. Marcus Aurelius. 2018. Meditations: Thoughts to Myself. Scotts Valley, CA: CreateSpace Independent Publishing Platform.

31. Marion, J.-L. 2012. In the Self's Place: The Approach of Saint Augustine. Stanford, CA: Stanford University Press.

32. Nadurak, V. 2018. “Two Types of Heuristics in Moral Decision Making”, Filosofija. Sociologija 29(3): 141-149.

33. Plato. 2006. The Republic. New Haven: Yale University Press.

34. Pruskus, V. 2005. Vertybès rinkoje: saveika ir pasirinkimas. Vilnius: Vilniaus pedagoginis universitetas, 26-34.

35. Pruskus, V. 2015. „Individo laikysenos valstybès puoselëjamų vertybių ir tikslų atžvilgiu etiniai aspektai“, Filosofija. Sociologija 26(1): 28-36.

36. Pruskus, V. 2016. „Individo siekiai ir vertybių pasirinkimas“, Filosofija. Sociologija 27(3): 199-205.

37. Robertson, R.; Turner, B. S. (eds.). 1991. Talcott Parsons. Theorist of Modernity. London, Newbury Park, New Delhi: SAGE Publications, 38-40.

38. Saint Augustine. 2008. Confessions. Series: Oxford World's Classics. Oxford: Oxford University Press. 39. „Salamankos deklaracija: specialusis ugdymas ir jo vystymo metmenys“. 1996. Švietimo naujoves 1: 3-21.

40. Salzmann, T. A. 1995. Deontology and Teleology: An Investigation of the Normative Debate in Roman Catholic Moral Theology. Leuven: Leuven University Press.

41. Seneca. 2016. Peace of Mind. Los Angeles, CA: Enhanced Media Publishing.

42. Seneca. 2018. Moral Letters to Lucilius. Scotts Valley, CA: CreateSpace Independent Publishing Platform.

43. Tomas Akvinietis. 1998. Žmogaus veikla dorovés požiūriu. Teologijos suma I-II. 18-21 klausimai (18-19 klausimai). Vilnius: Logos. 
VILIJA GRINCEVIČIENÉ, JOVILE் BAREVIČIŪTÉ, VAIDA ASAKAVIČIŪTÉ, VILIJA TARGAMADZE்

\title{
Lygios galimybės ir orumas kaip vertybès I. Kanto deontologinès etikos perspektyvoje: įtraukiojo ugdymo atvejis
}

\begin{abstract}
Santrauka
Siekiama atskleisti, kaip vertybių ir vertybinių nuostatų vieta individo ir visuomenès vertybinès raidos sistemoje koreliuoja su visuomenès, kuriai priklauso žmogus, branda, kultūra, ideologija bei socialinès sferos (ypač švietimo) kaitos erdvèmis ir linkmèmis. Pagrindinè straipsnio tezè - vertybių kaita ir vieta visuomenès vertybių skaleje suponavo specialiojo ugdymo erdvès kaitą ir linkmes, kurių viena - įtraukusis ugdymas. Mažoji tezè išsirutulioja iš pagrindinès - neiggalieji (vaikai, paaugliai, jaunimas) ir jų artimieji iki šiol susiduria su sunkumais šiems siekiant išsilavinimo: lygios galimybès ir orumas kaip vertybès atskirais atvejais tebèra siekiamybè. İsigilinus ị specialiojo ugdymo kaitos aspektus, akivaizdu, kad šalyje sukurta teisinio reglamentavimo bazè tik teoriškai garantuoja lygias galimybes siekiant išsilavinimo. Ilgalaikių tyrimų duomenys rodo, kad realybeje neigalieji neretai susiduria su ịvairiais sunkumais. Taigi, vertybès, interpretuojamos iš I. Kanto deontologinès etikos ir jo kategorinio imperatyvo perspektyvos ir deklaruojamos švietimo sistemą reglamentuojančiuose norminiuose dokumentuose, realybejje nèra pasiekusios bazinių vertybių kartelès: ugdymo procese neiggalūs asmenys neretai yra ignoruojami ar / ir diskriminuojami.
\end{abstract}

Raktažodžiai: vertybès, vertybinès nuostatos, ịtraukusis ugdymas, negalia, Kantas, deontologinè etika, pareiga, kategorinis imperatyvas, Kitas, kitybé 